\title{
Persistence among graduate nursing students enrolled in an online course
}

\author{
Peggy Ward-Smith, Carol Schmer, Jane Peterson, Carolyn Hart \\ School of Nursing and Health Studies, University of Missouri, Kansas City, USA
}

Correspondence: Peggy Ward-Smith. Address: University of Missouri, Kansas City, School of Nursing and Health Studies. 2464 Charlotte Street, Kansas City, MO. USA 64108. Email: wardsmithp@umkc.edu.

Received: November 29, 2012

Accepted: January 16, 2013

Online Published: February 27, 2013

DOI : $10.5430 /$ jnep.v3n9p48

URL: http://dx.doi.org/10.5430/jnep.v3n9p48

\section{Abstract}

Attrition in online courses, when compared to face-to-face courses, is higher. Student persistence affects the ability to complete an online course. The aim of this study was to quantitatively measure persistence among nursing students enrolled in a master's level required theory course. Study data, collected during the first two weeks of the semester, included responses to the Persistence Scale for Online Education (PSOE) and completion of a demographic data sheet. Data from 26 consented students revealed an overall moderate level of persistence. The four students who reported low levels of persistence failed to complete the course. It appears that the PSOE can reliably identify the student at-risk for course incompletion and may be useful in identifying those for whom intervention would be helpful.

\section{Key words}

Persistence, Online courses, Nursing

\section{Introduction}

According to the results of the Babson Survey ${ }^{[1]}$, a course may be classified as online when $80 \%$ or more of the content are delivered using web-based formats and is there is no face-to-face contact. Colleges are providing online courses as a means of allowing students to complete higher educational requirements while balancing life and work schedules. In the U.S., enrollment in online courses increased from 1.6 million in 2002 to 6.1 million in $2010^{[1]}$. This translates into an annual growth rate of $18.3 \%$. Online learning has become a mainstay of education with more than $50 \%$ of all Western universities incorporating distance education into programs of study ${ }^{[2]}$. Colleges and universities view online courses as crucial to their success and future planning ${ }^{[1]}$. Students' view online course as meeting their scheduling needs and more convenient compared to the traditional classroom ${ }^{[3-5]}$. Despite the growth in online courses, persistence, or the ability to complete the courses required for the degree, remain problematic. Research has identified a multitude of reasons which result in higher attrition rates in online courses ${ }^{[4,6,7]}$.

The term persistence, when related to post-secondary education, has been viewed as the opposite behavior of attrition or departure from college ${ }^{[8]}$. Berger and Braxton ${ }^{[9]}$ used intent to return to a program of study as a measure of persistence. Sadler ${ }^{[10]}$ states that attrition is the antonym of persistence and posits that it influences career decision-making, self-efficacy, perceived stress, financial attitudes, locus of control, and academic and social integration. Persistence in nursing education has been defined as the ability of the student to overcome obstacles and successfully complete a 
program of study, thereby predisposing to student success and mastery of content ${ }^{[11,12]}$. Persistence is the continued effort by the student towards online course completion, oftentimes despite obstacles or hardship ${ }^{[13]}$. Wood, Saylor, and Cohen ${ }^{[14]}$ offer similar support for a link between an external locus of control and student success. Table 1 presents a summary of those factors associated with persistence in the online student.

Table 1. Facilitators of Persistence

\begin{tabular}{|c|c|c|}
\hline Facilitators & Author & Synthesis of Studies \\
\hline $\begin{array}{l}\text { College status, graduating } \\
\text { term, comfort with online } \\
\text { course work }\end{array}$ & $15-16$ & $\begin{array}{l}\text { The closer to graduation, the more persistent the student. This may be related to } \\
\text { becoming more technologically savvy and comfortable with online instruction. }\end{array}$ \\
\hline $\begin{array}{l}\text { Flexibility, asynchronous } \\
\text { format. Time management }\end{array}$ & $4,6,15,17-18$ & $\begin{array}{l}\text { The flexibility of an online course is very attractive to student attempting to } \\
\text { balance work and family demands. The asynchronous format allows control over } \\
\text { one's schedule and course work can be accomplished with less disruption to } \\
\text { work and family schedules. Persistent students tend to have better study habits } \\
\text { and complete work in a timely manner. }\end{array}$ \\
\hline Goal Commitment & 6 & $\begin{array}{l}\text { Desire to attain goals (degree completion) is a powerful motivator in the online } \\
\text { student. This intrinsic motivation of pursuing a dream is often coupled with } \\
\text { personal challenge, an appreciation of learning, and personal responsibility. }\end{array}$ \\
\hline GPA & $19-20$ & $\begin{array}{l}\text { Students with a higher GPA are often able to better maneuver through the } \\
\text { electronic environment and adopt successful behaviors that allow them to excel } \\
\text { in the online course. It may be that success in one class positively motivates the } \\
\text { student to work harder in the next class. }\end{array}$ \\
\hline $\begin{array}{l}\text { Quality of interactions and } \\
\text { feedback }\end{array}$ & 6,21 & $\begin{array}{l}\text { Feedback that is constructive and adds meaningful input into learning is viewed } \\
\text { as valuable by the students and will contribute to persistence. Ambiguity in } \\
\text { content or communication can be difficult for the online student to process, thus } \\
\text { increasing the importance of quality interactions with faculty and other students. }\end{array}$ \\
\hline Satisfaction and relevance & $5-6,16-17$ & $\begin{array}{l}\text { Satisfaction as a facilitator of persistence is a consistent finding when included as } \\
\text { a variable. Persistent students voice satisfaction with the quality of the program, } \\
\text { interactions with students and peers, the relevancy of the course to individual } \\
\text { needs, and satisfaction with the learning environment itself. }\end{array}$ \\
\hline $\begin{array}{l}\text { Self-efficacy, personal growth, } \\
\text { self-motivation }\end{array}$ & $4-6,15,17,21$ & $\begin{array}{l}\text { Although goal attainment is a powerful motivator for online students, on a daily } \\
\text { basis personal resolve and determination contribute significantly to persistence. } \\
\text { Students who have high personal expectations and self-efficacy as well as those } \\
\text { who enjoy the challenge of online learning will also tend to be more persistent. } \\
\text { These characteristics may lead the student to engage more in the classroom, ask } \\
\text { searching questions, and constructively work through problems. A sense of } \\
\text { personal and professional growth can increase motivation to complete the course } \\
\text { and promote persistence. }\end{array}$ \\
\hline $\begin{array}{l}\text { Social connectedness or } \\
\text { presence }\end{array}$ & $6,20-21$ & $\begin{array}{l}\text { Increased comfort with the virtual social interactions of an online environment } \\
\text { may increase persistence. When these social connections are transient (i.e. vary } \\
\text { by course), they may not create a significant source of support, but instead may } \\
\text { create an encouraging environment. The persistent student is able to form } \\
\text { connections within each course, increasing the positive nature of the experience. } \\
\text { An active and encouraging faculty presence is also viewed as contributing to } \\
\text { persistence. }\end{array}$ \\
\hline Support & $4-6,15,20-21$ & $\begin{array}{l}\text { The role of family, friends, co-workers, and fellow class members in student } \\
\text { persistence is well documented. Understanding from family and co-workers in } \\
\text { behaviors needed to manage academic workload contributes to persistence. } \\
\text { Other class members can also provide support and encouragement to continue } \\
\text { with studies despite hardship. This virtual community provides a sense of } \\
\text { camaraderie and can assist students in troubleshooting problems. Faculty may } \\
\text { also increase perceptions of support through feedback and social presence. }\end{array}$ \\
\hline
\end{tabular}

Persistence, both a characteristic and an attitude, allows the student to master content, achieve their educational goal, and experience self-satisfaction ${ }^{[12,23,24]}$. Attributes which enhance persistence include determination to succeed, perceived satisfaction, course engagement, and positive interactions with the instructor and peers ${ }^{[10,14,23-25]}$. As a precursor to success, persistence can be positively influenced by the educator through such interventions as feedback, conversation, 
clear expectations, and social connectedness ${ }^{[23,24,26,28]}$. Certainly, personal challenges exist and can result in the failure to complete a course. These reasons, while related to persistence, maybe beyond the realm of any educational intervention.

According to Perry and associates ${ }^{[29]}$, unexpected changes in personal situations often result in the need to withdraw from an online course. Thus, a myriad of factors, controllable and uncontrollable, are required for sufficient persistence to be present to complete an online course. Despite an inherent inability to predict unforeseen and often adverse circumstances, attributes and precursors may serve to protect resilience for the student enrolled in an online course. For example, social and academic integration have long been held to positively influence persistence levels ${ }^{[30-32]}$ despite personal situational changes or a disengaged instructor.

The purpose of this study was to allow master in nursing students to self-describe their perceived persistence in the ability to complete an online nursing theory course. This course is typically the initial course taken within the master's program of study. Data were collected during the first two weeks of the course, making it possible to correlate these results with student success for course completion.

\section{The project}

The Persistence Scale for Online Education (PSOE) was developed to assess persistence in the student enrolled in an online course. Results of the PSOE allow the educator to objectively identify the student at risk for failure to complete the course, as opposed to failing the course. Based upon a review of the literature, the PSOE obtains data to describe student perceptions of social connectedness, perceived stress and support, self-determination, and goal attachment. Previously validated surveys were modified to develop the PSOE, thus providing construct validity. Face validity for the PSOE was achieved upon review by experienced nurse educators and a researcher with instrument development expertise. After revision, an initial feasibility study determined that the PSOE is reliable, based on a Cronbach's Alpha of $0.85^{\text {[33] }}$. The PSOE consists of 32 items; six of these items are descriptive, allowing each participant to self-describe student characteristics and previous experience with online courses, and 26 items are Likert-scaled. Possible responses for these items range from strongly agree (4) to strongly disagree (1), with a possible neutral response (0). Five items assess social connectedness (I look forward to reading other posts on the discussion board); six items assess perceived stress and support (I believe this institution is committed to providing quality education); seven items assess self-motivation (I have many personal strengths); and goal attachment is assessed by five items (When I set goals, I tend to succeed). Summing the responses to the 26 PSOE items determine persistence, as assessed by the constructs within the PSOE, and self-described by the student. Potential scores for the PSOE, as reported by the author (Hart, 2012), range from 0 to 104.

Institutional Review Board (IRB) approval was secured prior to collecting any study data. Each student enrolled in the Nursing Theory course received an email from the course instructor inviting then to participate in the study. If study participation was desired, the student was directed to the survey link in the Blackboard $\odot$ system ${ }^{[34]}$. As a survey, Blackboard@ allows the instructor to determine who completed the survey and obtain a total response score; the capability of determining responses to individual items is not feasible. Data were collected during the first two weeks of the semester, prior to any graded course assignment. This was to avoid course content that might impact the student's perceived persistence.

Study participation was offered to students enrolled the master's level Nursing Theory course. These individuals are beginning their educational process toward an advanced nursing degree, within one of six educational tracks (family, adult, pediatric, women's health, neonatal nurse practitioner, and nurse educator) programs. As such, these individuals have completed an undergraduate degree and have met the qualifications for admission into their respective program.

Enrollment rosters indicate that 34 students were enrolled in the Nursing Theory course. Data were obtained from 26 students, representing a $74 \%$ response rate. Demographically, these individuals may be described as female $(\mathrm{N}=23$; $88 \%$ ) 
and between the ages of 24 and 49 years (mean $=32.5$ years). Ninety six percent $(n=25)$ reported that this course was their first course in the Master's in Nursing Program and their first online course. Each of the six educational tracks was represented.

Reliability of the PSOE, determined by Cronbach's alpha, was .729, indicating that the survey was reliable. Scores on the PSOE ranged from 29 to 59 (mean $=47$, SD 7.7). This indicates that while these students self-described their persistence as high (positive responses to over 51\% of the items) none described their personal persistence as superior. The four students whose PSOE responses were between 19 and 46 (51\% to 68\%), or the lowest scores reported, failed to complete the course. Anecdotal data indicates that these individuals dropped the course as a result of misunderstanding the time commitment required for the course, computer access problems, child care difficulties, and an inability to negotiate decreased work responsibilities.

\section{Conclusion}

The results of this study indicate that the PSOE is capable of measuring persistence among students enrolled an online course. The PSOE appears to be capable of identify the student who, for a variety of reasons, is at risk for the inability to complete, rather than failing, an online course. The PSOE is not capable of identifying the reason for the inability to complete the course. Confidentially sharing individual results of the PSOE with students allows them to be aware of their 'at risk' status, which may encourage them to be proactive with issues, identified by the PSOE, that impact the ability to complete the course.

Further research, which includes administering the PSOE to nursing students in different academic tracks, different geographical locations, and with diverse ethnicity are necessary to further delineate its psychometric properties, generalizability, and educational usefulness. The PSOE provides a method to quantitatively assess persistence, as it impacts the ability to complete an online course. The results of this study support previous research indicating that persistence is an important component in educational success.

\section{References}

[1] Allen, I.E., \& Seaman, J. Going the distance: Online Education in the United States. 2011. Available from: http://sloanconsortium.org/publications/survey/survey05.asp

[2] Bocci, J., Eastman, J.K., \& Swift, C.O. Retaining the online learner: Profile of students in an online MBA program and implications for teaching them. Journal of Education for Business. 2004 Mar/April; 79(4): 245-253. http://dx.doi.org/10.3200/JOEB.79.4.245-253

[3] Buckley, K.M. Evaluation of classroom-based, Web-enhanced, and Web-based distance learning nutrition courses for undergraduate nursing. Journal of Nursing Education. 2003; 42(8): 367-370. PMid:12938900

[4] Holder, B. An investigation of hope, academics, environment, and motivation as predictors of persistence in higher education online programs. The Internet and Higher Education. 2007; 10: 245-260. http://dx.doi.org/10.1016/j.iheduc.2007.08.002

[5] Park, J.H., \& Choi, H.J. Factors influencing adult learners' decision to drop out or persist in online learning. Educational Technology \& Society. 2009; 12(4): 207-217.

[6] Ivankova, N.V., \& Stick, S.L. Collegiality and community-building as a means for sustaining student persistence in the computer-mediated asynchronous learning environment. Online Journal of Distance Learning Administration. 2005; 8(3): e1-7.

[7] Joo, Y.J., Lim, K.Y., \& Kim, E.K. Online university students' satisfaction and persistence: Examining perceived level of presence, usefulness and ease of use as predictors in a structural model. Computers \& Education. 2011; 57: 1654-1664. http://dx.doi.org/10.1016/j.compedu.2011.02.008

[8] Greer, L. Persistence and academic success among non-traditional age students at a junior college. Paper presented at the Annual Forum of the Association for Institutional Research. Retrieved from the ERIC database. 1980.

[9] Berger, J.B., \& Braxton, J.M. Revising Tinto's interactionalist theory of student departure through theory elaboration: Examining the role of organizational attributes in the persistence process. Research in Higher Education. 1998; 39(2): 103-119. http://dx.doi.org/10.1023/A:1018760513769

Published by Sciedu Press 
[10] Sadler, J. Attitude of Health Personnel, Questionnaires. Sigma Theta Tau International, Honor Society of Nursing. 2000; 26(2): 8-9.

[11] Demaris, M. C., \& Kritsonis, W. A. The classroom: Exploring its effects on student persistence and satisfaction. Focus on Colleges, Universities, and Schools. 2008; 1(2): 1-9.

[12] Gardner, H. Multiple intelligences; New horizons. New York, NY. Basic Books. 2006.

[13] Hart, C. The persistence scale for online education: Development of a psychometric tool. (Doctoral dissertation). 2012. Available from: https://mospace.umsystem.edu/xmlui/handle/10355/14050.

[14] Wood, A.M., Saylor, C., \& Cohen, J. Locus on control and academic success among ethnically diverse baccalaureate students. Nursing Educator Perspective. 2009; 30(5): 290-295. PMid:19824238

[15] Bunn, J. Student persistence in a LIS distance education program. Australian Academic Research Libraries. 2004; 35(3): $253-270$.

[16] Levy, Y. Comparing dropouts and persistence in e-learning courses. Computers and Education. 2007; 48: 185-204. http://dx.doi.org/10.1016/j.compedu.2004.12.004

[17] Müller, T. Persistence of women in online degree-completion programs. International Review of Research in Open and Distance Learning. 2008; 9(2): 1-18

[18] Stanford-Bowers, D.E. Persistence in online classes: A study of perceptions among community college stakeholders. Journal of Online Learning and Teaching. 2008; 4(1). Available from: http://jolt.merlot.org/vol4no1/stanfordbowers0308.pdf

[19] Harrell, I.L., \& Bower, B.L. Student characteristics that predict persistence in community college online courses. American Journal of Distance Education. 2011; 25(3): 178-191. http://dx.doi.org/10.1080/08923647.2011.590107

[20] Muse, H.E. The web-based community college student: An examination of factors that lead to success and risk. The Internet and Higher Education. 2003; 6: 241-261. http://dx.doi.org/10.1016/S1096-7516-(03)00044-7

[21] Kemp, W.C. Persistence of adult learners in distance education. The American Journal of Distance Education. 2002; 16(2): 65-81. http://dx.doi.org/10.1207/S15389286AJDE1602_2

[22] Ojokheta, K.O. A path-analytic study of some correlates predicting persistence and student's success in distance education in Nigeria. Turkish Online Journal of Distance Education. 2010; 11(1).

[23] McGivney, V. Understanding persistence in adult learning. Open Learning. 2004; 19(1): 33-46. http://dx.doi.org/10.1080/0268051042000177836

[24] Yorke, M. Retention, persistence and success in on-campus higher education and their enhancement in open and distance learning. Open Learning. 2004; 19(1): 19-32. http://dx.doi.org/10.1080/0268051042000177827

[25] Deci, E. L., \& Ryan, R. M. Facilitating optimal motivation and psychological well-being across life’s domains. Canadian Psychology. 2008; 49: 14-23. http://dx.doi.org/10.1037/0708-5591.49.1.14

[26] Bonnel, W. Improving feedback to students in online courses. Nursing Education Perspectives. 2008; $29(5): 290-294$. PMid:18834059

[27] Cantrell, S. Fullerton, J., Kane, T. J. \& Staiger, D. O. National Board Certification and Teacher Effectiveness: Evidence from a Random Assignment Experiment. Technical Report: National Board for Professional Teaching Standards. 2008. http://dx.doi.org/10.3386/w14608

[28] Holmberg, B. The conversational approach to distance education. Open Learning. 1999; 14(3): 58-60. http://dx.doi.org/10.1080/0268051990140309

[29] Perry, B., Bowman, J., Care, W.D., Edwards, M., \& Park, C. Why do students withdraw from online graduate nursing and health studies education? The Journal of Educators Online. 2008; 5 (1). Available from:

http://www.thejeo.com/Archives/Volume5Number1/PerryetalPaper.pdf

[30] Kember, D. A longitudinal-process model of drop-out from distance education. The Journal of Higher Education. 1989; 60(3): 278-301. http://dx.doi.org/10.2307/1982251

[31] Park, J. Factors related to learner dropout in online learning. In Nafukho, F. M., Chermack, T. H., \& Graham, C. M. (Eds.) Proceedings of the 2007 Academy of Human Resource Development Annual Conference (pp. 25-1-25-8). Indianapolis, IN: AHRD. 2007.

[32] Tinto, V. Leaving college: Rethinking the causes and cures of student attrition (2nd ed.). Chicago, IL: University of Chicago Press. 1993.

[33] Hart, C. Assessing persistence in the online student: The persistence scale for online education in nursing. Nursing Education Perspectives (in press). 2013.

[34] Blackboard@. Blackboard Educational Platform for Online Teaching and Learning. 2012. Available from:

http://www.blackboard.com/ 